\title{
Beta Amyloid 42 Measurement
}

National Cancer Institute

\section{Source}

National Cancer Institute. Beta Amyloid 42 Measurement. NCI Thesaurus. Code C84809.

The determination of the amount of the 1-42 amino acid beta amyloid protein isoform present in a sample. 